CLINICAL STUDY

\title{
Upregulation of CDKN2A and suppression of cyclin D1 gene expressions in ACTH-secreting pituitary adenomas
}

\author{
Yuji Tani, Naoko Inoshita ${ }^{1}$, Toru Sugiyama, Masako Kato, Shozo Yamada ${ }^{2}$, Masayoshi Shichiri ${ }^{3}$ and Yukio Hirata \\ Department of Clinical and Molecular Endocrinology, Tokyo Medical and Dental University Graduate School, 1-5-45, Yushima, Bunkyo-ku, Tokyo \\ 113-8519, Japan, Departments of ${ }^{1}$ Pathology and ${ }^{2}$ Hypothalamic and Pituitary Surgery, Toranomon Hospital, Tokyo 105-8470, Japan and ${ }^{3}$ Department \\ of Endocrinology, Diabetes and Metabolism, School of Medicine, Kitasato University, Kanagawa 252-0375, Japan \\ (Correspondence should be addressed to Y Hirata; Email: yhirata.cme@tmd.ac.jp)
}

\begin{abstract}
Objective: Cushing's disease (CD) is usually caused by ACTH-secreting pituitary microadenomas, while silent corticotroph adenomas (SCA) are macroadenomas without Cushingoid features. However, the molecular mechanism(s) underlying their different tumor growth remains unknown. The aim of the current study was to evaluate and compare the gene expression profile of cell cycle regulators and cell growth-related transcription factors in CD, SCA, and non-functioning adenomas (NFA).

Design and methods: Tumor tissue specimens resected from 43 pituitary tumors were studied: CD $(n=10)$, SCA $(n=11)$, and NFA $(n=22)$. The absolute transcript numbers of the following genes were quantified with real-time quantitative PCR assays: CDKN2A (or $\left.p 16^{I N K 4 a}\right)$, cyclin family $(A 1, B 1$, D1, and E1), E2F1, RB1, BUB1, BUBR1, ETS1, and ETS2. Protein expressions of p16 and cyclin D1 were semi-quantitatively evaluated by immunohistochemical study.

Results and conclusion: CDKN2A gene expression was about fourfold greater in CD than in SCA and NFA. The gene expressions of cyclins D1, E1, and B1, but not of $A 1$, in CD were significantly suppressed than those in NFA. Cyclin D1 gene expression positively correlated with cyclins $B 1$ and $E 1$. The gene expressions of E2F1, RB1, BUB1, BUBR1, ETS1, and ETS2 did not differ between each group. Positive immunostaining for p16 and negative immunostaining for cyclin D1 were more frequent in CD than in NFA; there were positive correlations between mRNA and protein expressions of p16 and cyclin D1. Thus, it is suggested that upregulated CDKN2A with the concomitant downregulated cyclin gene family is partly involved in the small size of ACTH-secreting adenoma.
\end{abstract}

European Journal of Endocrinology 163 523-529

\section{Introduction}

ACTH-secreting pituitary tumors causing Cushing's disease $(\mathrm{CD})$ with a resultant hypercortisolism are usually microadenomas (1). In contrast, silent corticotroph adenomas (SCA) associated with positive immunoreactivity for $\mathrm{ACTH}$, but not associated with signs and symptoms of Cushing's syndrome, present as macroadenomas (2) partly due to the delayed diagnosis resulting from the hormonal inactivity. However, the differences in molecular mechanisms underlying cell cycle regulation between ACTH-secreting microadenoma and SCA remain incompletely characterized.

Cyclin D1-induced activation of cyclin-dependent kinases (CDK4 and CDK6) is one of the most important mechanisms in the $G_{1}$ to $S$ phase transition of the cell cycle, which causes phosphorylation of retinoblastoma protein $(\mathrm{pRb})$ and subsequent release of E2F transcription factors to induce the expression of genes required for the $S$ phase entry (3). Cyclin-CDK complexes are regulated by a family of kinase inhibitors that prevent phosphorylation of the corresponding substrates (4). Cyclin-dependent kinase inhibitor $2 \mathrm{~A}\left(\mathrm{CDKN} 2 \mathrm{~A}\right.$ or $\left.\mathrm{p} 16^{\mathrm{INK} 4 \mathrm{a}}\right)$ is a member of the protein family that specifically inhibits cyclin D-dependent kinases, which leads to the suppression of phosphorylation and activation of $\mathrm{pRb}$ (5). It has been reported that CDKN2A is mutated or inactivated in a variety of primary tumors and cancer cell lines $(6,7)$. Moreover, overexpression of CDKN2A has been shown to cause $\mathrm{G}_{1}$ arrest in pituitary tumor cells (8), and an inverse association between CDKN2A and pRb alterations was observed in certain human cancers $(9,10)$. Recent molecular analysis revealed deregulation of cell cycle in human pituitary tumorigenesis (11); aberrations of one or more components of the $\mathrm{pRb} / \mathrm{CDKN} 2 \mathrm{~A} / \mathrm{cyclin}$ D1/CDK4 pathway seem to be a frequent event in pituitary adenoma (12-14). The most common mechanism of $\mathrm{pRb} / \mathrm{CDKN} 2 \mathrm{~A}$ inactivation involves methylation in their gene promoter region.

However, the expression profile of cell cycle regulatory genes, such as retinoblastoma 1 (RB1) and CDKN2A, in pituitary corticotroph adenoma is still controversial regardless of methylation status, and the deranged expression of $C D K N 2 A$ gene in relation to the 
clinical characteristics of human pituitary tumors has not been investigated thus far.

Therefore, we studied the differential expression profile of cell cycle regulators and cell growth-related transcription factors in CD and SCA, and compared with those in non-functioning adenomas (NFA) using a realtime RT-PCR and immunohistochemical study.

\section{Patients and methods}

\section{Patients}

Forty-three patients (15 males and 28 females, mean age $51.2 \pm 2.1$ years), who underwent transsphenoidal surgery for removal of pituitary tumors at the Department of Hypothalamic and Pituitary Surgery, Toranomon Hospital and Tokyo Medical and Dental University, were studied. Informed consent was obtained from each patient before surgery. Tumor size was evaluated by the largest tumor diameter on magnetic resonance imaging. Blood samples were obtained in a resting supine position at $0800 \mathrm{~h}$ after overnight fast on three separate occasions. Plasma ACTH and serum cortisol levels were measured by IRMA and enzyme immunoassay respectively; the average values were used. Pituitary corticotroph adenoma was defined as ACTH-secreting pituitary adenoma causing CD, SCA as ACTH-positive pituitary adenomas without clinical stigmata of Cushing's syndrome as originally described (15), and NFA as clinically non-functioning pituitary adenomas other than SCA.

\section{Real-time quantitative PCR assay}

The tissue specimens were prepared as described previously (16). Total RNA was extracted from pituitary tumors (30-200 mg), and $5 \mu \mathrm{g}$ total RNA were reverse transcribed. The transcripts of the following genes were quantified with Chromo4-based (Bio-Rad Laboratories) real-time RT-PCR using fluorescent SYBR Green Technology essentially as described (16, 17). A sequence-specific standard curve generated using 10 -fold serial dilutions $\left(10^{7}-10^{3}\right.$ copies per capillary reaction) of the standard PCR product of each target gene, which had been purified by Wizard SV Gel and PCR Clean-Up System (Promega), was included in each run to determine the absolute gene copy number per microgram RNA. Universal Probe Library System (Roche) combined with TaqMan Technology which prevents generation of non-specific amplification products was used to quantify the following genes: CDKN2A, E2F transcription factor 1 (E2F1), RB1, cyclin family (cyclins $A 1, B 1, D 1$, and E1), budding uninhibited by benzimidazoles 1 homolog family (BUB1 and BUBR1), E-twenty-six family (ETS1 and ETS2), glyceraldehyde-3-phosphate dehydrogenase (GAPDH), and $\beta$-actin. The PCR primers were synthesized by Greiner Bio-One (Tokyo, Japan), and their sequences are shown in Table 1. Non-specific amplification in the SYBR Green assay was estimated from typical amplification curve, such as very high quantification results, early $C_{t}$ value, and/or the linearity of the serially diluted purified cDNA standard. The cDNAs of all tumor

Table 1 PCR primers used for real-time RT-PCR.

\begin{tabular}{|c|c|c|c|}
\hline Primers & Probe & Sequences & $\begin{array}{l}\text { PCR product } \\
\text { size }(\mathrm{bp})\end{array}$ \\
\hline$C D K N 2 A\left(p 16^{I N K 4 a}\right)$ & \#34 & $\begin{array}{l}\text { Forward: gtggacctggctgaggag } \\
\text { Reverse: ctttcaatcggggatgtctg }\end{array}$ & 132 \\
\hline$E 2 F 1$ & \#5 & $\begin{array}{l}\text { Forward: tccaagaaccacatccagtg } \\
\text { Reverse: ctgggtcaacccctcaag }\end{array}$ & 75 \\
\hline$R B 1$ & \#55 & $\begin{array}{l}\text { Forward: tcaccttgaatctgcttgtcc } \\
\text { Reverse: tggagatcttacaggagaaagataca }\end{array}$ & 88 \\
\hline CCNA1 (Cyclin A1) & \#71 & $\begin{array}{l}\text { Forward: tcagtaccttagggaagctgaaa } \\
\text { Reverse: ccagtccaccagaatcgtg }\end{array}$ & 103 \\
\hline CCNB1 (Cyclin B1) & $\# 18$ & $\begin{array}{l}\text { Forward: catggtgcactttcctcctt } \\
\text { Reverse: aggtaatgttgtagagttggtgtcc }\end{array}$ & 102 \\
\hline CCND1 (Cyclin D1) & \#67 & $\begin{array}{l}\text { Forward: gaagatcgtcgccacctg } \\
\text { Reverse: gacctcctcctcgcacttct }\end{array}$ & 61 \\
\hline CCNE1 (Cyclin E1) & \#36 & $\begin{array}{l}\text { Forward: ggccaaaatcgacaggac } \\
\text { Reverse: gggtctgcacagactgcat }\end{array}$ & 75 \\
\hline$B \cup B 1$ & \#69 & $\begin{array}{l}\text { Forward: ggagaacgctctgtcagca } \\
\text { Reverse: tccaaaaactcttcagcatgag }\end{array}$ & 71 \\
\hline$B U B R 1$ & $\# 7$ & $\begin{array}{l}\text { Forward: gaaggacaaaagatcctggcta } \\
\text { Reverse: tgtgctaaatctgctataccaaaca }\end{array}$ & 74 \\
\hline ETS1 & \#50 & $\begin{array}{l}\text { Forward: ccatcatcaagacggaaaaag } \\
\text { Reverse: gggacatctgcacattccata }\end{array}$ & 70 \\
\hline ETS2 & \#20 & $\begin{array}{l}\text { Forward: cccctgtggctaacagttaca } \\
\text { Reverse: ggacccatcaaaggtgtcaa }\end{array}$ & 68 \\
\hline$G A P D H$ & \#60 & $\begin{array}{l}\text { Forward: gctctctgctcctcctgttc } \\
\text { Reverse: acgaccaaatccgttgactc }\end{array}$ & 115 \\
\hline$\beta$-Actin & \#64 & $\begin{array}{l}\text { Forward: ccaaccgcgagaagatga } \\
\text { Reverse: tccatcacgatgccagtg }\end{array}$ & 121 \\
\hline
\end{tabular}




\section{O CD $\square$ SCA $\triangle$ NFA}

(a) Cyclin $A 1$
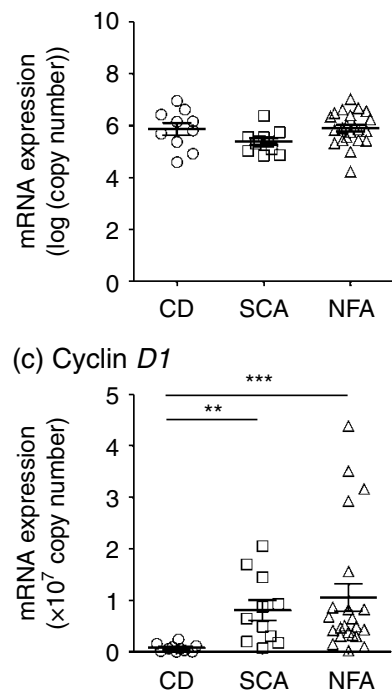

(b) Cyclin $B 1$

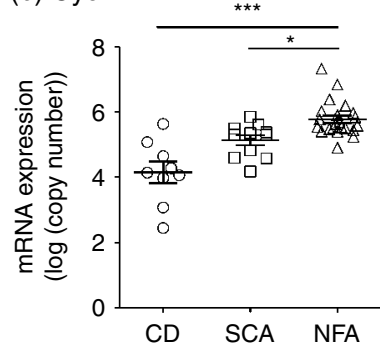

(d) Cyclin E1

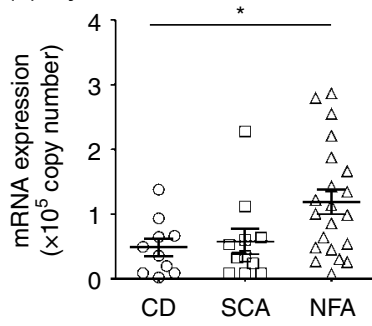

Figure 1 Gene expression profiles of cyclin family in $\mathrm{CD}, \mathrm{SCA}$, and NFA. Transcript copy numbers per microgram RNA of (a) cyclin A1, (b) cyclin $B 1$, (c) cyclin $D 1$, and (d) cyclin $E 1$, as determined by real-time quantitative RT-PCR are shown. Each point with bars shows mean \pm S.E.M. ${ }^{*} P<0.05,{ }^{* \star} P<0.01$, and ${ }^{\star \star *} P<0.001$.

specimens were prepared in a single run. Failure in RNA quality and/or RT reaction was estimated from very low transcript results. Such cDNA samples were subjected to repetition of RNA re-extraction and quantification, and then assessed using TaqMan PCR protocol.

\section{Immunohistochemistry}

Immunostaining was performed by the avidin-biotinperoxidase complex (ABC) method using an autostaining machine (Ventana Benchmark HX System, Ventana Medical System, Tucson, AZ, USA). Primary antibodies used in this study were mouse monoclonal anti-p16 (clone JC8, Santa Cruz, San Diego, CA, USA; diluted 1:200) and rabbit monoclonal anti-cyclin D1 (clone SP4, Dako, Glostrup, Denmark; diluted 1:100). Hematoxylin was used as counterstain. The resulting sections were examined blind, without any prior knowledge of pituitary subtype by a single observer. The percentage of nuclear staining of p16 and cyclin D1 was evaluated semi-quantitatively as follows: p16, (-) negative staining; $(1+)<20 \%$; $(2+) \quad 20-50 \% ;(3+)>50 \%$ and cyclin D1, (-) <10\%; (+) 10-50\%; $(2+)$ $50-70 \%$, $(3+)>70 \%$.

\section{Statistical analyses}

Data are expressed as means \pm s.e.m. Differences between groups were examined for statistical significance using Kruskal-Wallis test with Dunn's post-hoc test. The relations between two continuous variables were evaluated using Spearman's rank correlation coefficient. $P$ values $<0.05$ were considered statistically significant. All the statistical analyses were performed using Windows software Prism 5.0 (GraphPad Software, La Jolla, CA, USA).

\section{Results \\ Clinical characteristics and laboratory data of the patients}

Based on clinical, endocrinological, and immunohistochemical studies, 10 patients (one male and nine females, aged $43.8 \pm 4.3$ years) were diagnosed to have $\mathrm{CD}, 11$ (one male and 10 females, aged $50.6 \pm 3.8$ years) SCA, and 22 (13 males and 9 females, aged 55.0 \pm 2.8 years) NFA.

The female to male ratio in CD and SCA was greater $(P<0.001)$ than that in NFA. There were no statistical differences in age among the three groups $(P=0.12)$. The tumor sizes in CD $(10.4 \pm 2.6 \mathrm{~mm})$ were significantly $(P<0.001)$ smaller than those in SCA $(40.2 \pm 9.0 \mathrm{~mm})$ and NFA $(29.8 \pm 1.6 \mathrm{~mm})$. Both plasma ACTH levels $(202.2 \pm 38.9 \mathrm{pg} / \mathrm{ml})$ and serum cortisol levels $(33.3 \pm 5.8 \mu \mathrm{g} / \mathrm{dl})$ in CD were significantly $(P<0.001)$ higher than those in SCA (ACTH, $31.0 \pm 3.4 \mathrm{pg} / \mathrm{ml}$ and cortisol, $10.7 \pm 1.1 \mu \mathrm{g} / \mathrm{dl}$ ) and NFA (ACTH, 26.2 $\pm 2.3 \mathrm{pg} / \mathrm{ml}$ and cortisol, $12.6 \pm 0.8 \mu \mathrm{g} / \mathrm{dl}$ ) respectively.

\section{Expression profile of cyclin family}

We first quantified mRNA copy numbers of cyclin family in CD, SCA, and NFA (Fig. 1). Copy number of cyclin A1 mRNAs did not differ among the three groups, while that of cyclin $B 1$ mRNAs in NFA $\left(1.8 \pm 1.0 \times 10^{6}\right)$ was greater than that in $\mathrm{CD}\left(6.5 \pm 4.2 \times 10^{4}\right)(P<0.001)$ and SCA $\left(2.2 \pm 0.6 \times 10^{5}\right)(P<0.05)$. Copy numbers of cyclin D1 mRNAs in SCA $\left(8.1 \pm 2.0 \times 10^{6}\right)$ and NFA $\left(10.6 \pm 2.6 \times 10^{6}\right)$ were markedly $(P<0.001)$ greater than those in $\mathrm{CD}\left(7.7 \pm 2.4 \times 10^{5}\right)$, while that of

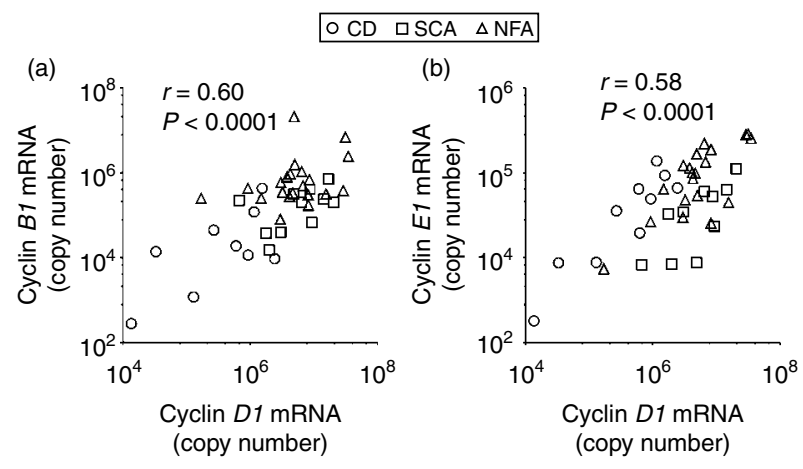

Figure 2 Correlations of cyclin gene expression in CD, SCA, and NFA. Univariate positive correlations of cyclin D1 mRNA levels with those of (a) cyclin $B 1$ and (b) cyclin $E 1$ are shown. 
cyclin E1 mRNAs in NFA $\left(11.9 \pm 1.9 \times 10^{4}\right)$ were significantly greater than those in CD $\left(4.9 \pm 1.4 \times 10^{4}\right)$ $(P<0.05)$. There were significant positive correlations between cyclin $B 1$ and cyclin $D 1(r=0.60, P<0.0001)$, as well as between cyclin $D 1$ and cyclin $E 1(r=0.58$, $P<0.0001$ ) mRNA levels (Fig. 2). We also performed analyses between tumors of comparable size by excluding the largest SCA/NFAs and the smallest CDs. There were similar differences in cyclins/CDKIs expressions among the three groups after matching for the tumor size.

\section{Expression profile of genes related to $R B$ pathway}

We next studied the expression profile of genes interacting with RB pathway. Copy number of cell cycle inhibitor CDKN2A mRNAs in CD $(1.4 \pm 0.3$ $\left.\times 10^{6}\right)$ was significantly $(P<0.05)$ greater than that in SCA $\left(2.0 \pm 0.5 \times 10^{5}\right)$ and NFA $\left(3.8 \pm 0.9 \times 10^{5}\right)$, whereas copy number of the transcription factor $E 2 F 1$ or RB1 did not show any significant differences among the three groups (Fig. 3).

The expressions of neither transcription family (ETS1 and ETS2) regulating CDKN2A gene nor the cell cycle checkpoint genes (BUB1 and BUBR1) showed any significant differences among the three tumor groups (data not shown). The same results were obtained after matching for the tumor size.

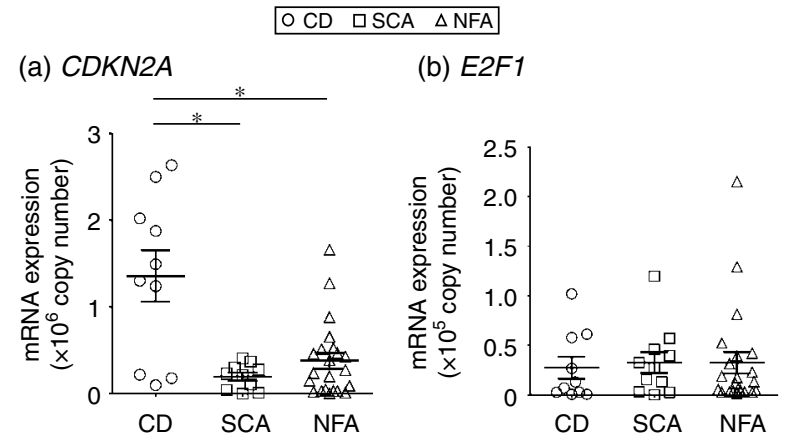

(c) RB1

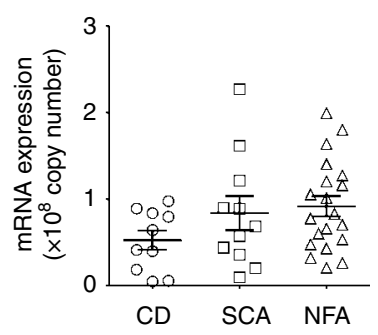

Figure 3 Gene expression profiles of cell cycle inhibitor and transcription factors in CD, SCA, and NFA. Transcript copy numbers per microgram RNA of (a) CDKN2A, (b) E2F1, and (c) $R B 1$, as determined by real-time quantitative RT-PCR are shown as in Fig. 1. ${ }^{\star} P<0.05$.
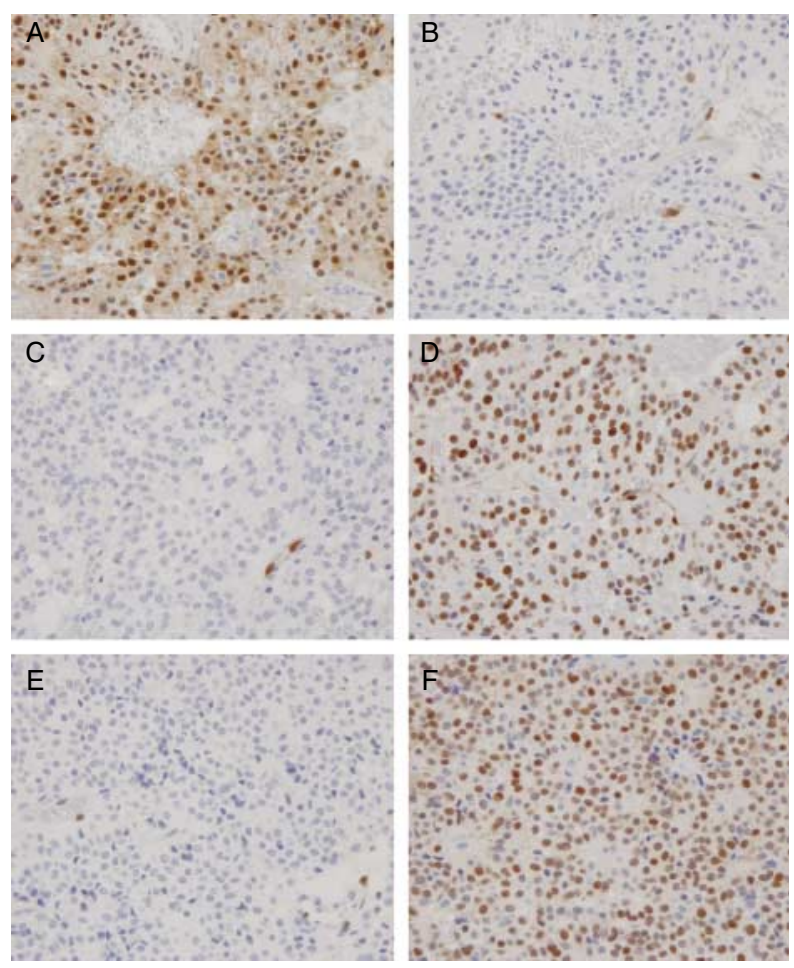

Figure 4 Immunohistochemical analysis of CDKN2A and cyclin D1 in pituitary tumors. Typical immunostainings for CDKN2A (left panels) and cyclin D1 (right panels) are shown in CD (A and B), SCA (C and D), and NFA $(E$ and $F)$ (magnification $\times 100)$. Full colour version of this figure available via http://dx.doi.org/10.1530/EJE-10-0245.

\section{CDKN2A and cyclin D1 immunohistochemis- try and protein expression}

As shown in Fig. 4 and Table 2, positive immunostaining cells for CDKN2A was observed in 8 out of $9(89 \%)$ cases in $\mathrm{CD}, 5$ out of $8(63 \%)$ cases in SCA, and 4 out of 15 $(27 \%)$ cases in NFA. In contrast, positive immunostaining cells for cyclin D1 was observed in only 2 out of $9(22 \%)$ cases in CD, but in all cases $(100 \%)$ in SCA and NFA. Based on the immunohistochemical semiquantitative grading score of CDKN2A and cyclin D1 (Table 2), there were significant differences of copy numbers of mRNA expression between the groups (CDKN2A: $P<0.04$; cyclin D1: $P<0.01)$. Copy number of CDKN2A mRNA $\left(1.4 \pm 0.4 \times 10^{6}\right)$ in $(2+)$ group was significantly $(P<0.05)$ greater than that $(1.7 \pm 0.4$ $\left.\times 10^{5}\right)$ in $(-)$ group, while copy number of cyclin $D 1$ mRNA $\left(4.6 \pm 0.6 \times 10^{6}\right)$ in $(3+)$ group was significantly $(P<0.01)$ greater than that $\left(8.0 \pm 3.5 \times 10^{5}\right)$ in $(-)$ group (Fig. 5).

\section{Discussion}

By real-time quantitative RT-PCR, our study revealed the gene expression profile of a variety of cell cycle regulators and cell growth-related transcription factors 
Table 2 CDKN2A and cyclin D1 expressions as evaluated by immunohistochemical study.

\begin{tabular}{lrcrr}
\hline & \multicolumn{4}{c}{ Protein expression } \\
\cline { 2 - 5 } $\begin{array}{l}\text { Tumor type } \\
\text { (no. of cases) }\end{array}$ & $(-)$ & $1+$ & $2+$ & $3+$ \\
\hline (A) CDKN2A & & & & \\
CD (9) & 1 & 3 & 4 & 1 \\
SCA (8) & 3 & 3 & 2 & 0 \\
NFA (15) & 11 & 4 & 0 & 0 \\
(B) Cyclin D1 & & & & \\
CD (9) & 7 & 2 & 0 & 0 \\
SCA (8) & 0 & 0 & 3 & 5 \\
NFA (15) & 0 & 0 & 3 & 12 \\
\hline
\end{tabular}

The percentage of nuclear staining of CDKN2A was evaluated as follows: $(-)$ negative staining, $(1+)<20 \%,(2+) 20-50 \%,(3+)>50 \%$. The percentage of nuclear staining of cyclin D1 was evaluated as follows: $(-)<10 \%,(+)$ 10-50\%, (2+) 50-70\%, (3+) > 70\%. CD, ACTH-secreting pituitary tumors causing Cushing's disease; SCA, silent corticotroph adenoma; NFA, non-functioning pituitary adenoma.

in ACTH-secreting tumors causing $\mathrm{CD}$ to compare with those in SCA and NFA. We have established highly sensitive quantification protocols on many different human genes in our laboratory $(16,17)$; our quantification experiments using both SYBR Green and TaqMan real-time RT-PCR protocols are more accurate than the conventional RT-PCR methods. The amplification curve of each SYBR Green-based PCR was carefully reviewed to negate the presence of non-specifically amplified products, and the absolute copy numbers per microgram RNA were calculated after confirming the close linearity of serially diluted purified target cDNA. Insufficient quality of RNA and failure of RT were easily detected by quantifying a wide spectrum of genes, including 'house-keeping' genes, not restricted to cell cycle regulators and transcription factors. Additionally, the conventional RT-PCR methods widely used to

\begin{tabular}{|lll|}
\hline $\mathrm{O}$ CD & $\square \mathrm{SCA}$ & $\triangle \mathrm{NFA}$ \\
\hline
\end{tabular}

(a) CDKN2A

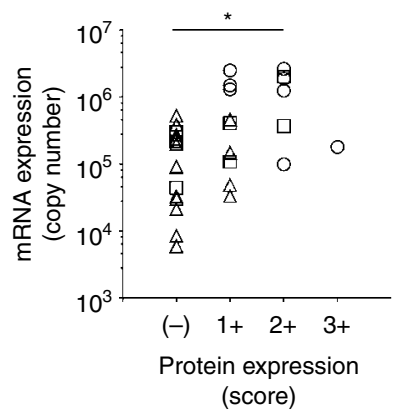

(b) Cyclin D1

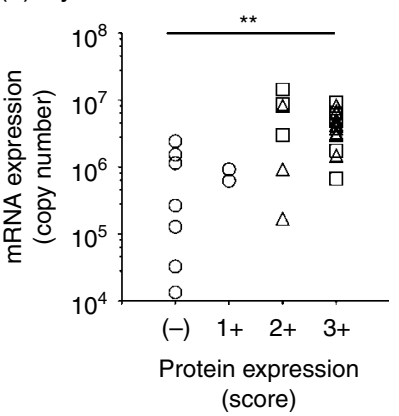

Figure 5 Correlations of gene and protein expressions of p16 and cyclin D1 in CD, SCA, and NFA. Correlations between mRNA levels by real-time quantitative RT-PCR and protein expression by immunohistochemical semi-quantitative grading score are shown for (a) CDKN2A and (b) cyclin D1. There were significant differences between the groups: CDKN2A $(P<0.04)$ and cyclin D1 $(P<0.01)$. Dunn's post hoc test compared with each group: ${ }^{\star} P<0.05$ and ${ }^{\star *} P<0.01$. evaluate the gene expression in most studies thus far reported simply 'normalize' the quantification results by house-keeping genes which, however, are influenced by several factors, thereby yielding erroneous results. Such technical maneuvers are absolutely important to draw any definite conclusion from the gene expression analysis of the resected tumors obtained during surgery, such as ACTH-secreting pituitary microadenomas.

Recent molecular analyses of human pituitary neoplasias showed deregulation of cell cycle in pituitary tumorigenesis, such as altered CDK regulation (11) and suppressed CDKN2A gene expression (18). It has been reported that cyclin D1 is often overexpressed in pituitary tumors (19), with its allelic imbalance in some tumor samples being analyzed (20). It has also been reported that a single null CDKN2A phenotype did not result in pituitary tumorigenesis (21), and that CDKN2A hypermethylation was the most common epigenetic deregulation in these neoplasias $(12,22)$. As for subtypes of pituitary adenoma, some reports have shown that clinically non-functioning macroadenoma has impaired CDKN2A expression compared with other pituitary tumor subtypes $(23,24)$, while other reports have shown that protein expression of p16 was downregulated in all the pituitary tumors (18), and that high frequency of CDKN2A methylation did not differ between non-functioning and functioning adenomas (25). However, in the pituitary corticotroph adenomas in particular, the relationship between tumor size and the expression of CDKN2A has been undetermined yet.

Indeed, the hormonal inactivity allows the tumor to grow to a large size as a macroadenoma until the clinical manifestations develop in SCA and NFA, whereas hormonally active tumors are diagnosed earlier as a microadenoma due to the overt symptoms and signs of hypercortisolism. This may be another logical explanation of high incidence of microadenoma causing $\mathrm{CD}$. However, the present study clearly showed enhanced CDKN2A gene expression concomitant with markedly suppressed cyclin D1 gene expression in ACTH-secreting pituitary tumors causing CD. Such change could decrease the activation of CDK4, thereby leading to suppression of $\mathrm{pRb}$ phosphorylation. In other words, the reduced CDKN2A expression representing removal of 'cell cycle brake' in SCA and NFA may lead to unchecked cell proliferation. Moreover, the upregulation of CDKN2A expression in corticotroph adenomas could partly contribute to the reduced cyclin genes expression along with epigenetic inactivation of cyclin $D 1$ gene, thereby leading to the repression of cell cycles and tumor growth. This hypothesis is consistent with a previous study showing that CDKN2A-negative pituitary tumors were larger than CDKN2A-positive ones (24), and that oncogenic aberrations of CDKN2A and cyclin D1 cooperate to deregulate $\mathrm{G}_{1}$ control (26). Thus, these results could at least in part account for the mechanism(s) for the 'small size' of ACTH-secreting adenoma compared to SCA and NFA. 
Recent report has shown that cyclin E is significantly increased in corticotroph adenomas (19), speculating that overexpression of cyclin $\mathrm{E}$ is relevant to low expression of p27 in corticotroph adenomas. In contrast, our study clearly showed that cyclin E1 expression is much reduced in corticotroph adenomas and correlated well with cyclin D1 expression, suggesting that overexpression of cyclin D1 may lead to E2F-mediated cyclin E1 transcription (4), which could be regulated by p16 rather than by $\mathrm{p} 27$. Such contradictory results could be accounted for by the complex mechanism(s) of CKIs regulation involved and/or the different methods (RT-PCR versus immunohistochemical analysis) employed in each study.

A pivotal role of $\mathrm{pRb}$ inactivation in pituitary tumorigenesis has been well recognized, such as loss of heterozygosity (27) and decreased expression with hypermethylation of its promoter (28). Our study showed no apparent differences in RB1 at its gene expression level, although a possible involvement of $\mathrm{pRb}$ activation in the mechanism of growth inhibition in corticotroph adenomas could not be excluded. However, it is reasonable to assume that the increased expression of cyclin D1 leads to hyperphosphorylation of $\mathrm{pRb}$ via a cyclin D1/CDK4 complex.

Neither transcription factors (ETS1 and ETS2) known to activate the CDKN2A promoter nor mitotic check point genes (BUB1 and BUBR1) revealed any differences among the three tumor groups, suggesting a negative involvement of the altered expression of such genes in corticotroph adenomas.

The exact mechanism(s) of concomitantly downregulated cyclin family (D1, E1 and B1) and upregulated $C D K N 2 A$ gene in ACTH-secreting pituitary tumors causing $\mathrm{CD}$ as demonstrated in our study remains unsettled. It has been reported that glucocorticoids suppress the growth of murine corticotrophic tumor cells (AtT20) in vitro (29), and that the size of the corticotroph adenomas correlates with the degree of insensitivity to glucocorticoid feedback in dogs in vivo (30). Consistent with these studies, our study showed that ACTH-secreting pituitary adenomas were smaller than SCA and NFA, suggesting that cortisol excess may have contributed to the size differences. Furthermore, promoter region of CDKN2A contains putative binding sites for CEBPB (C/EBP $\beta)$, which is induced by glucocorticoid and mediates its effect (31). Collectively, glucocorticoid excess may directly contribute to the upregulation of CDKN2A in ACTH-secreting pituitary tumors, although the correlation between CDKN2A expression and circulating cortisol level was not significant in our study (unpublished observation). Thus, further study using larger sample size of CD patients is required. Moreover, our data with a significant reduced expression of cyclin D1 in ACTHsecreting pituitary tumors are consistent with those of other studies showing that glucocorticoids inhibit cell proliferation by virtue of their ability to downregulate cyclin D expression in lymphoid cell (32).

In conclusion, our data revealed for the first time the enhanced expression of CDKN2A with concomitant suppressed expression of cyclin family (D1, E1, and B1) in ACTH-secreting pituitary tumors causing $\mathrm{CD}$, which may in part contribute to the small tumor size. However, it remains to be determined whether glucocorticoidinduced gene expression of CDKN2A is related to epigenetic inactivation of cyclin D1 gene, and whether inactivation of $\mathrm{pRb}$ pathway is related to reduced growth rate of corticotroph adenomas.

\section{Declaration of interest}

The authors declare that there is no conflict of interest that could be perceived as prejudicing the impartiality of the research reported.

\section{Funding}

This research did not receive any specific grant from any funding agency in the public, commercial, or not-for-profit sector.

\section{Acknowledgements}

This study was supported in part by the Grant-in-aid from the Ministry of Education, Science, Sports and Culture, and the Ministry of Health, Welfare and Labor of Japan. We thank Dr T Tateno for his cooperation in this study.

\section{References}

1 Boscaro M, Barzon L, Fallo F \& Sonino N. Cushing's syndrome. Lancet 2001357 783-791. (doi:10.1016/S0140-6736(00) 04172-6)

2 Horvath E, Kovacs K, Killinger DW, Smyth HS, Platts ME \& Singer W. Silent corticotropic adenomas of the human pituitary gland: a histologic, immunocytologic, and ultrastructural study. American Journal of Pathology 198098 617-638.

3 Harbour JW \& Dean DC. The Rb/E2F pathway: expanding roles and emerging paradigms. Genes and Development 200014 2393-2409. (doi:10.1101/gad.813200)

4 Sherr CJ \& Roberts JM. CDK inhibitors: positive and negative regulators of $\mathrm{G}_{1}$-phase progression. Genes and Development 1999 13 1501-1512. (doi:10.1101/gad.13.12.1501)

5 Serrano M, Hannon GJ \& Beach D. A new regulatory motif in cell-cycle control causing specific inhibition of cyclin D/CDK4. Nature 1993366 704-707. (doi:10.1038/366704a0)

6 Merlo A, Herman JG, Mao L, Lee DJ, Gabrielson E, Burger PC, Baylin SB \& Sidransky D. $5^{\prime}$ CpG island methylation is associated with transcriptional silencing of the tumour suppressor p16/CDKN2/MTS1 in human cancers. Nature Medicine 19951 686-692. (doi:10.1038/nm0795-686)

7 Herman JG, Merlo A, Mao L, Lapidus RG, Issa JP, Davidson NE, Sidransky D \& Baylin SB. Inactivation of the CDKN2/p16/MTS1 gene is frequently associated with aberrant DNA methylation in all common human cancers. Cancer Research 199555 4525-4530.

8 Frost SJ, Simpson DJ, Clayton RN \& Farrell WE. Transfection of an inducible p16/CDKN2A construct mediates reversible growth inhibition and $\mathrm{G}_{1}$ arrest in the AtT20 pituitary tumor cell line. Molecular Endocrinology 199913 1801-1810. (doi:10.1210/ me.13.11.1801) 
9 Aagaard L, Lukas J, Bartkova J, Kjerulff AA, Strauss M \& Bartek J. Aberrations of $\mathrm{p} 16^{\text {Ink4 }}$ and retinoblastoma tumour-suppressor genes occur in distinct sub-sets of human cancer cell lines. International Journal of Cancer 199561 115-120. (doi:10.1002/ ijc. 2910610120)

10 Szijan I, Orlow I, Dalamon V, Vergani P, Danilowicz K, Mezzadri N, Cordon-Cardo C \& Bruno OD. Alterations in the retinoblastoma pathway of cell cycle control in parathyroid tumors. Oncology Reports 20007 421-425.

11 Malumbres M \& Barbacid M. To cycle or not to cycle: a critical decision in cancer. Nature Reviews. Cancer 2001 1 222-231. (doi:10.1038/35106065)

12 Yoshino A, Katayama Y, Ogino A, Watanabe T, Yachi K, Ohta T, Komine C, Yokoyama T \& Fukushima T. Promoter hypermethylation profile of cell cycle regulator genes in pituitary adenomas. Journal of Neuro-Oncology 200783 153-162. (doi:10.1007/ s11060-006-9316-9)

13 Simpson DJ, Frost SJ, Bicknell JE, Broome JC, McNicol AM, Clayton RN \& Farrell WE. Aberrant expression of $\mathrm{G}(1) / \mathrm{S}$ regulators is a frequent event in sporadic pituitary adenomas. Carcinogenesis 200122 1149-1154. (doi:10.1093/carcin/22.8. 1149)

14 Musat M, Morris DG, Korbonits M \& Grossman AB. Cyclins and their related proteins in pituitary tumourigenesis. Molecular and Cellular Endocrinology, 2010. (doi:10.1016/j.mce.2010.03.017)

15 Kovacs K, Horvath E, Bayley TA, Hassaram ST \& Ezrin C. Silent corticotroph cell adenoma with lysosomal accumulation and crinophagy. A distinct clinicopathologic entity. American Journal of Medicine $1978 \mathbf{6 4} 492-499$. (doi:10.1016/00029343(78)90236-X)

16 Tateno T, Izumiyama H, Doi M, Yoshimoto T, Shichiri M, Inoshita N, Oyama K, Yamada S \& Hirata Y. Differential gene expression in ACTH-secreting and non-functioning pituitary tumors. European Journal of Endocrinology 2007157 717-724. (doi:10.1530/EJE-07-0428)

17 Shichiri M, Yoshinaga K, Hisatomi H, Sugihara K \& Hirata Y. Genetic and epigenetic inactivation of mitotic checkpoint genes hBUB1 and hBUBR1 and their relationship to survival. Cancer Research 200262 13-17.

18 Woloschak M, Yu A, Xiao J \& Post KD. Frequent loss of the $\mathrm{P} 16^{\text {INK4a }}$ gene product in human pituitary tumors. Cancer Research 199656 2493-2496.

19 Jordan S, Lidhar K, Korbonits M, Lowe DG \& Grossman AB. Cyclin $\mathrm{D}$ and cyclin $\mathrm{E}$ expression in normal and adenomatous pituitary. European Journal of Endocrinology 2000143 R1-R6. (doi:10. 1530/eje.0.143R001)

20 Hibberts NA, Simpson DJ, Bicknell JE, Broome JC, Hoban PR, Clayton RN \& Farrell WE. Analysis of cyclin D1 (CCND1) allelic imbalance and overexpression in sporadic human pituitary tumors. Clinical Cancer Research 19995 2133-2139.

21 Quereda V \& Malumbres M. Cell cycle control of pituitary development and disease. Journal of Molecular Endocrinology 200942 75-86. (doi:10.1677/JME-08-0146)
22 Simpson DJ, Bicknell JE, McNicol AM, Clayton RN \& Farrell WE. Hypermethylation of the p16/CDKN2A/MTSI gene and loss of protein expression is associated with nonfunctional pituitary adenomas but not somatotrophinomas. Genes, Chromosomes and Cancer 199924 328-336. (doi:10.1002/(SICI)1098-2264 (199904)24:4<328::AID-GCC6>3.0.CO;2-P)

23 Machiavelli G, Cotignola J, Danilowicz K, Carbonara C, Paes de Lima A, Basso A, Bruno OD \& Szijan I. Expression of p16(INK4A) gene in human pituitary tumours. Pituitary 200811 71-75. (doi:10.1007/s11102-007-0077-z)

24 Seemann N, Kuhn D, Wrocklage C, Keyvani K, Hackl W, Buchfelder M, Fahlbusch R \& Paulus W. CDKN2A/p16 inactivation is related to pituitary adenoma type and size. Journal of Pathology 2001 193 491-497. (doi:10.1002/path.833)

25 Ogino A, Yoshino A, Katayama Y, Watanabe T, Ota T, Komine C, Yokoyama T \& Fukushima T. The p15(INK4b)/p16(INK4a)/RB1 pathway is frequently deregulated in human pituitary adenomas. Journal of Neuropathology and Experimental Neurology $20056 \mathbf{4}$ 398-403.

26 Lukas J, Aagaard L, Strauss M \& Bartek J. Oncogenic aberrations of p16INK4/CDKN2 and cyclin D1 cooperate to deregulate $\mathrm{G}_{1}$ control. Cancer Research 199555 4818-4823.

27 Pei L, Melmed S, Scheithauer B, Kovacs K, Benedict WF \& Prager D. Frequent loss of heterozygosity at the retinoblastoma susceptibility gene (RB) locus in aggressive pituitary tumors: evidence for a chromosome 13 tumor suppressor gene other than RB. Cancer Research 199555 1613-1616.

28 Simpson DJ, Hibberts NA, McNicol AM, Clayton RN \& Farrell WE. Loss of pRb expression in pituitary adenomas is associated with methylation of the RB1 CpG island. Cancer Research 200060 1211-1216.

29 van Wijk PA, van Neck JW, Rijnberk A, Croughs RJ \& Mol JA. Proliferation of the murine corticotropic tumour cell line AtT20 is affected by hypophysiotrophic hormones, growth factors and glucocorticoids. Molecular and Cellular Endocrinology 1995111 13-19. (doi:10.1016/0303-7207(95)03541-E)

30 Kooistra HS, Voorhout G, Mol JA \& Rijnberk A. Correlation between impairment of glucocorticoid feedback and the size of the pituitary gland in dogs with pituitary-dependent hyperadrenocorticism. Journal of Endocrinology 1997152 387-394. (doi:10. $1677 /$ joe.0.1520387)

31 Gotoh T, Chowdhury S, Takiguchi M \& Mori M. The glucocorticoid-responsive gene cascade. Activation of the rat arginase gene through induction of C/EBPbeta. Journal of Biological Chemistry 1997272 3694-3698. (doi:10.1074/jbc.272.30.18602)

32 Reisman D \& Thompson EA. Glucocorticoid regulation of cyclin D3 gene transcription and mRNA stability in lymphoid cells. Molecular Endocrinology 19959 1500-1509. (doi:10.1210/ me.9.11.1500)

Received 6 June 2010

Accepted 5 July 2010 